\title{
ANALISIS KOMPARASI PENDAPATAN USAHATANI KAKAO DAN USAHATANI LADA DI DESA LAMONG JAYA KECAMATAN LAEYA KABUPATEN KONAWE SELATAN
}

\author{
Siti Aisah \\ Azhar Bafadal \\ Yusna Indarsyih \\ Jurusan/Program Studi Agribisnis Fakultas Pertanian \\ Universitas Halu Oleo, Kendari \\ Hp: 082349042 520, Email: Sitiaisah697@rocketmail.com
}

\begin{abstract}
This research aims to determine the income and differences of income of cocoa and pepper farming. This research was conducted from June until October 2015. The samples were selected through a non-probability sampling. The samples are taken purposively with the criteria of the respondents who had planted cocoa and pepper plant since 5 until 10 years ago, and both of these commodities are in the productive age, so this research used 35 respondents of cocoa farmer and 29 respondents of pepper farmer. The Data were collected through interviews by questionnaire. This research used income analysis and t-test analysis or Independent sample $t$-test. The result of this research shows that average income cocoa farmers is $R p 7,637,358$ per year, and the average income of pepper farmers is $R p 11,724,301$ per year. Where as the average per hectare income of cocoa farming is $R p$ 6,048,775/halyear and the average per hectare income of pepper farmin is $R p 17,108,435 /$ halyear. The average income of respondents who are farming cocoa is different with average income of respondents who are farming pepper as significantly. Beside of that, the average per hectare income of cocoa farming is different with average income of pepper farming significantly.
\end{abstract}

Keywords: Comparison, Income, Farming, Cocoa, Pepper

QE Journal | Vol.04 - No.04 December 2015 - 250 


\section{PENDAHULUAN}

ndonesia dikenal sebagai negara agraris artinya pertanian memegang peranan penting dari seluruh perekonomian nasional. Hal ini dapat ditunjukkan banyaknya penduduk yang hidup dan bekerja pada sektor pertanian atau dari produk nasional yang berasal dari pertanian. Oleh karena itu, pembangunan bangsa dititik beratkan pada sektor pertanian. Pembangunan pertanian bertujuan meningkatkan hasil dan mutu produksi, meningkatkan pendapatan petani, memperluas lapangan kerja dan kesempatan berusahatani dan menunjang pembangunan industri serta ekspor. Sejalan dengan tujuan pembangunan pertanian, salah satu kebijaksanaan pembangunan pertanian adalah mengembangkan sub sektor perkebunan yang diarahkan pada pengembangan perkebunan rakyat. Sub sektor perkebunan merupakan lapangan usahatani yang menyerap banyak tenaga kerja, penyedia bahan baku untuk bahan industri pengolahan dan berperan dalam pelestarian lingkungan hidup, karena itu usahatani untuk mengembangkan sub sektor ini perlu terus ditingkatkan (Soekartawi, 2003).

Sulawesi Tenggara merupakan salah satu propinsi di kawasan Indonesia Timur yang memiliki lahan kering cukup luas, yang sebagian penduduknya menyandarkan kebutuhan hidup dibidang pertanian khususnya sub sektor perkebunan. Komoditas unggulan Provinsi Sulawesi Tenggara khususnya sub sektor perkebunan yang dikembangkan diantaranya yaitu komoditas kelapa, kakao, kopi, cengkeh, jambu mete, dan lada (Badan Pusat Statistik, 2014). Luas lahan komoditas kakao di Sulawesi Tenggara berada pada urutan pertama jika dibandingkan dengan komoditas perkebunan yang lain, sedangkan luas lahan komoditas lada berada pada urutan kelima setelah kakao, jambu mete, kelapa, dan cengkeh seperti ditunjukkan pada Tabel 1.

Tabel 1. Luas Lahan dan Produksi Komoditas Perkebunan Sulawesi Tenggara, Tahun 2013.

\begin{tabular}{llll}
\hline No. & Jenis Komoditas & Luas Lahan $(\mathrm{Ha})$ & Produksi (Ton) \\
\hline 1. & Kakao & 245.624 & 185.201 \\
2. & Jambu Mete & 117.414 & 25.882 \\
3. & Kelapa & 57.348 & 30.047 \\
4. & Cengkeh & 17.949 & 9.415
\end{tabular}

QE Journal | Vol.04 - No.04 December 2015 - 251 


$\begin{array}{llll}\text { 5. } & \text { Lada } & 13.079 & 4.405 \\ \text { 6. } & \text { Kopi } & 9.542 & 3.685\end{array}$

sumber: badan pusat statistik, 2014

Berdasarkan Tabel 1 menunjukkan bahwa luas lahan komoditas kakao mencapai 245.624 hektar dan produksinya 185.201 ton, perkembangan kakao tersebut didukung dengan adanya pelaksanaan Gerakan Nasional (Gernas) kakao di Sulawesi Tenggara. Kakao memiliki peranan penting bagi masyarakat dan dunia usaha karena kakao merupakan mata pencaharian sebagian besar penduduk. Sedangkan komoditas lada memiliki luasan sebesar 13.079 hektar dengan produksi yaitu 4.405 ton, hal ini dikarenakan tanaman ini mudah mati atau terserang penyakit busuk batang sehingga perlu perlakuan khusus dalam pembudidayaannya.

Dilihat dari sebaran komoditas menurut kabupaten, maka sentra pengembangan kakao dan lada terbesar terdapat pada lima kabupaten. Dimana Kabupaten Konawe Selatan merupakan salah satu kabupaten yang menjadi sentra komoditas kakao dengan luas lahan berada pada urutan keempat dan komoditas lada berada pada urutan kedua dari kabupatenkabupaten lain yang ada di Sulawesi Tenggara. Luas lahan dan produksi komoditas kakao maupun lada disajikan pada Tabel 2.

Berdasarkan Tabel 2 diketahui bahwa komoditas kakao di Kabupaten Konawe Selatan memiliki luas lahan sebesar 20.054 hektar dan produksinya sebesar 8.900 ton. Sedangkan luas lahan komoditas lada lebih sempit yaitu sebesar 3.049 hektar dengan produksi sebesar 1.084 ton. Komoditas kakao di Konawe Selatan dibudidayakan oleh masyarakat karena umur produksi kakao yang lama. Komoditas lada merupakan penghasil devisa dan memiliki nilai jual tinggi serta memiliki banyak manfaat oleh karena itu masyarakat di Konawe Selatan mulai membudidayakan tanaman tersebut walaupun lahannya masih sempit namun tanaman ini cukup menjanjikan.

Tabel 2. Luas Lahan dan Produksi Komoditas Kakao dan Lada Menurut Kabupaten, Provinsi Sulawesi Tenggara Tahun 2013

\begin{tabular}{llll}
\hline \multicolumn{3}{l}{ Komoditas Kakao } & \\
\hline No. & Kabupaten & Luas Lahan $(\mathrm{Ha})$ & Produksi (Ton) \\
\hline 1. & Kolaka Utara & 71.691 & 102.662 \\
2. & Kolaka Timur & 66.765 & 32.023
\end{tabular}

QE Journal | Vol.04 - No.04 December 2015 - 252 


\begin{tabular}{llll}
3. & Kolaka & 29.167 & 8.563 \\
4. & Konawe Selatan & 20.054 & 8.900 \\
5. & Muna & 16.657 & 12.612 \\
\hline \multicolumn{2}{l}{ Komoditas Lada } & \\
\hline No. & Kabupaten & Luas Lahan (Ha) & Produksi (Ton) \\
\hline 1. & Konawe & 3.562 & 1.226 \\
2. & Konawe Selatan & 3.049 & 1.084 \\
3. & Kolaka Timur & 3.030 & 574 \\
4. & Kolaka & 1.541 & 754 \\
5. & Kolaka Utara & 542 & 216 \\
\hline
\end{tabular}

Sumber: Badan Pusat Statistik, 2014a.

Dari sisi luas lahan, komoditas kakao memiliki luas lahan yang lebih besar dibandingkan komoditas lada sehingga produksi kakao yang dihasilkan akan lebih besar. Salah satu kecamatan yang mengembangkan komoditas kakao dan lada di Kabupaten Konawe Selatan yaitu Kecamatan Laeya dimana secara umum Kecamatan Laeya memiliki luas lahan perkebunan sebesar 3.440 hektar yang tersebar diberbagai desa. Perkembangan luas lahan dan produksi komoditas kakao dan lada dapat dilihat pada Tabel 3.

Tabel 3. Perkembangan Luas Lahan dan Produksi Komoditas Kakao dan Lada Kecamatan Laeya, Tahun 2012-2013

\begin{tabular}{llllll}
\hline \multirow{2}{*}{ No } & \multirow{2}{*}{ Komoditi } & \multicolumn{3}{c}{ Luas Lahan (Ha) } & \multicolumn{2}{l}{ Produksi (Ton) } \\
\cline { 3 - 6 } & & 2012 & 2013 & 2012 & 2013 \\
\hline 1. & Kakao & 158 & 825,34 & 221 & 19.482 \\
2. & Lada & 20 & 52,18 & 2 & 3.037 \\
\hline
\end{tabular}

Sumber: Badan Pusat Statistik, 2014b

Berdasarkan Tabel 3 tampak bahwa komoditas kakao mengalami peningkatan luas lahan yaitu $80,9 \%$ dan produksi sebesar $98,9 \%$, begitupula dengan komoditas lada mengalami peningkatan luas lahan sebesar $61,7 \%$ dan produksi meningkat sebesar 99,9\%, luas lahan kakao lebih besar daripada lada karena adanya program Gernas sehingga mempengaruhi besarnya jumlah produksi. Luas lahan lada masih sempit karena tanaman lada mudah mati dan ditanam berdasarkan ketertarikan masyarakat terhadap harganya yang tinggi.

Desa Lamong Jaya merupakan salah satu desa di Kecamatan Laeya yang memiliki keadaan iklim tropis dan merupakan daerah berbukit dimana kondisi geografis tersebut sangat cocok untuk dikembangkan tanaman 
perkebunan seperti kakao dan lada. Secara umum luas lahan untuk perkebunan yaitu sebesar 162 hektar, dimana luas lahan untuk kakao yaitu 30 hektar dan luas lahan lada mencapai 15 hektar (Kecamatan Laeya, 2013). Luas lahan garapan tersebut secara langsung akan berpengaruh terhadap peningkatan jumlah tanaman kakao dan lada dan pada akhirnya dapat meningkatkan produksi tanaman sehingga pendapatan akan usahatani meningkat. Desa ini bukanlah desa yang mempunyai luas lahan dan rerataan hasil perkebunan yang tinggi diantara desa-desa lain di Kecamatan Laeya namun hampir seluruh masyarakat yang ada di desa tersebut mengusahakan komoditas kakao dan lada dimana dari 330 kepala keluarga ada 27,3\% kepala keluarga yang mengusahakan kakao dan 18,2\% kepala keluarga mengusahakan lada (Kecamatan Laeya, 2013).

Dari sisi harga pasar secara nasional, harga kakao tanggal 5 Agustus 2014 memiliki harga yaitu sebesar $\mathrm{Rp} 33.500 / \mathrm{Kg}$, berbeda dengan kakao harga lada yang berlaku yaitu sebesar Rp 150.000/Kg (BAPPEBTI, 2014). Sedangkan dari sisi harga pasar yang berlaku di Desa Lamong Jaya pada bulan Oktober sampai Desember 2014 yang dilihat dari harga menurut Kabupaten Konawe Selatan mengalami perubahan harga setiap bulannya dimana harga tersebut lebih rendah dari harga nasional seperti yang ditunjukkan pada Tabel 4 berikut.

Tabel 4. Harga Komoditas Kakao dan Lada di Desa Lamong Jaya, Bulan Oktober-Desember, Tahun 2014

\begin{tabular}{lllll}
\hline \multirow{2}{*}{ No } & \multirow{2}{*}{ Komoditi } & \multicolumn{3}{l}{ Harga komoditas/Bulan } \\
& & Oktober & November & Desember \\
\hline 1. & Kakao & 23.750 & 23.000 & 22.750 \\
2. & Lada & 78.000 & 72.500 & 72.500 \\
\hline
\end{tabular}

Sumber: Dinas Perkebunan, 2014

Berdasarkan Tabel 4 menunjukkan bahwa harga kakao pada bulan Oktober sampai Desember selalu mengalami penurunan harga sedangkan lada sempat mengalami penurunan harga pada bulan Oktober ke November namun di bulan November dan Desember harganya stabil. Dengan adanya perbedaan harga tersebut ternyata tidak mempengaruhi petani untuk mengganti usahataninya karena jika dilihat dari sisi harga memang lada memiliki harga jual yang lebih tinggi dibandingkan kakao namun jika dilihat dari sisi waktu panen kakao dapat dipanen setiap minggu dan umur produksinya lebih lama daripada lada.

QE Journal | Vol.04 - No.04 December 2015 - 254 
Usahatani kakao dan lada masing-masing memiliki keunggulan dan kelemahan. Sebagaimana uraian di atas, kakao unggul dari segi luas lahan yang lebih besar dibandingkan lada selain itu pemanenannya bisa setiap minggu namun harga yang berlaku ditingkat petani masih rendah. Keunggulan lada terletak pada harga pasar yang tinggi dibanding kakao dan masa pemanenannya lebih cepat daripada kakao namun produksinya masih rendah karena luas lahannya juga masih sempit. Oleh karena itu, penelitian ini dilakukan untuk mendiskusikan mengenai sejauhmana perbedaan pendapatan usahatani kakao dan usahatani lada.

Nirmalasari, dkk (2013) melakukan penelitian tentang "Analisis Perbandingan Pendapatan Usahatani Gula Merah dengan Usahatani Gula Tapo (Studi Kasus di Desa Ambesia Kecamatan Tomini Kabupaten Parigi Moutong)". Hasil penelitian diperoleh bahwa rata-rata pendapatan usahatani gula merah sebesar Rp 498.449/bulan dan pendapatan usahatani gula tapo yang diperoleh sebesar Rp 2.437.639/bulan dengan hasil uji $t$ sebesar $-6,982$ dan $t$ tabel sebesar 2,048 yang mengindikasikan bahwa $t$ hitung $>\mathrm{t}$ tabel yang berarti terdapat perbedaan yang nyata antara pendapatan usahatani gula merah dengan pendapatan usahatani gula tapo di Desa Ambesia Kecamatan Tomini Kabupaten Parigi Moutong.

Gusti, dkk., (2013) melakukan penelitian tentang "Pendapatan Rumahtangga Petani Kakao di Desa Pesawaran Indah Kecamatan Padang Cermin Kabupaten Pesawaran". Hasil penelitian menunjukkan bahwa pendapatan rumahtangga petani kakao di Desa Pesawaran Indah sebesar Rp18.790.360,70/tahun. Sebesar 76,02\% pendapatan ini diperoleh dari kegiatan usahatani kakao, 23,10\% dari kegiatan non usahatani, dan 0,87\% diperoleh dari kegiatan usahatani selain kakao. Distribusi pendapatan rumahtangga petani kakao di Desa Pesawaran Indah tergolong sedang. Hal ini ditunjukkan oleh angka Gini Rasio distribusi pendapatan sebesar 0,46 (Oshima) dan 0,38 (Bank Dunia). Penguasaan lahan oleh rumahtangga petani kakao sudah merata atau tidak terjadi ketimpangan dengan nilai indeks gini sebesar 0,36 (Oshima) dan 1,07 (Bank Dunia). 


\section{METODE PENELITIAN}

Populasi dalam penelitian ini adalah semua petani di Desa Lamong Jaya Kecamatan Laeya yang membudidayakan tanaman kakao (petani kakao) yaitu 90 kepala keluarga dan petani yang membudidayakan lada yaitu sebanyak 60 kepala keluarga. Penentuan sampel dilakukan secara non probability sampling dimana sampel diambil secara purposive atau secara sengaja (Sugiyono, 2011). Jumlah sampel untuk responden petani kakao sebesar 35 orang dan responden petani lada sebesar 29 orang. Kriteria responden yang dapat mendukung penelitian ini adalah:

1. Responden telah menanam kakao atau lada 5 sampai 10 tahun yaitu sejak tahun 2005.

2. Tanaman kakao dan lada masih berada pada umur produktif.

Data primer diperoleh dari responden kakao dan responden lada sedangkan data sekunder diperoleh dari BPS dan instansi terkait yang berhubungan dengan penelitian ini.

Besarnya pendapatan dari petani kakao dan petani lada dapat diketahui dengan menggunakan analisis pendapatan (Suratiyah, 2006), yang diformulasikan sebagai berikut:

$$
\begin{aligned}
& \mathrm{I}=\mathrm{TR}-\mathrm{TC} \\
& \mathrm{TR}=\mathrm{P} \cdot \mathrm{Q} \\
& \mathrm{TC}=\mathrm{TFC}+\mathrm{TVC}
\end{aligned}
$$

\section{Keterangan:}

$\mathrm{I}=$ Income (Pendapatan), (Rp)

$\mathrm{TR}=$ Total Revenue (Penerimaan Total), $(\mathrm{Rp})$

$\mathrm{TC}=$ Total Cost $($ Biaya Total), (Rp)

$\mathrm{P}=$ Harga Produk Kakao, Lada (Price), $(\mathrm{Rp})$

$\mathrm{Q}=$ Jumlah Produksi Kakao, Lada (Quantity), (Kg)

$\mathrm{TFC}=$ Total Fixed Cost $($ Biaya Tetap Total),$(\mathrm{Rp})$

TVC $=$ Total Variable Cost (Biaya Variabel Total), (Rp) 


\section{Uji t-test (Independent t-test sample)}

Perbandingan pendapatan dari usahatani kakao dan usahatani lada dapat diketahui dengan menggunakan analisis uji beda rata-rata t-test.

$$
\mathrm{t}=\frac{\bar{X}_{1}-\bar{X}_{2}}{\sqrt{\frac{\left(n_{1}-1\right) S_{1}^{2}+\left(n_{2}-1\right) S_{2}^{2}}{n_{1}+n_{2}-2}\left(\frac{1}{n_{1}}+\frac{1}{n_{2}}\right)}}
$$

Keterangan:

$\mathrm{t}=$ Nilai uji statistik atau $t_{\text {hitung }}$

$\bar{X}_{1}=$ Pendapatan rata-rata usahatani kakao

$\bar{X}_{2}=$ Pendapatan rata-rata usahatani lada

$\mathrm{n}_{1}=$ Banyaknya responden kakao

$\mathrm{n}_{2}=$ Banyaknya responden lada

$s_{1}^{2}=$ Simpangan baku/variansi pendapatan kakao

$s_{2}^{2}=$ Simpangan baku/variansi pendapatan lada

\section{Hipotesis:}

Ho: $\bar{X}_{1}=\bar{X}_{2}$

Ha: $\bar{X}_{1} \neq \bar{X}_{2}$

Dimana:

Ho: Tidak ada perbedaan pendapatan antara usahatani kakao dengan usahatani lada

Ha: Terdapat perbedaan pendapatan antara usahatani kakao dengan usahatani lada

Dengan kriteria pengujian :

Jika nilai $t_{\text {hitung }}>t_{\text {tabel }}$ maka Ho ditolak dan Ha diterima sehingga terdapat perbedaan yang nyata antara pendapatan responden yang mengusahakan kakao dengan responden yang mengusahakan lada. Sebaliknya, jika nilai $t_{\text {hitung }}<t_{\text {tabel }}$ maka Ho diterima dan Ha ditolak sehingga tidak terdapat perbedaan pendapatan antara responden yang mengusahakan kakao dan responden yang mengusahakan lada. Nilai $t$ tabel diperoleh dengan melihat nilai distribusi $\mathrm{t}$ dimana dilihat dari nilai $\mathrm{df}$ yang diperoleh dari hasil uji t dengan nilai $\alpha=0,05$. 


\section{HASIL DAN PEMBAHASAN}

\section{Luas Lahan}

Menurut Hermanto (1989) mengemukakan bahwa ada tiga golongan petani berdasarkan luas lahan yang digarapnya yakni $<0,5$ hektar berarti kategori luas lahan sempit, 0,5 - 2 hektar berarti kategori luas lahan sedang, dan $>2$ hektar berarti kategori luas. Luas lahan yang dimiliki oleh responden dapat dilihat pada Tabel 5 .

Tabel 5. Luas Lahan Responden, Tahun 2015

\begin{tabular}{llllll}
\hline \multirow{2}{*}{ No. } & \multirow{2}{*}{ Jenis Usahatani } & \multicolumn{3}{l}{ Luas Lahan $(\mathrm{Ha})$} & \\
\cline { 3 - 5 } & & $\begin{array}{l}\text { Sempit } \\
(<0,5 \mathrm{Ha})\end{array}$ & $\begin{array}{l}\text { Sedang } \\
(0,5-2 \mathrm{Ha})\end{array}$ & $\begin{array}{l}\text { Luas } \\
(>2 \mathrm{Ha})\end{array}$ & \\
\hline 1. & Kakao & 3 & 32 & 0 & 35 \\
2. & Lada & 17 & 12 & 0 & 29 \\
\hline
\end{tabular}

Luas lahan lada masih sempit karena menurut responden dengan lahan tersebut jika tanaman lada benar-benar dirawat maka sudah bisa menghasilkan produksi yang tinggi, namun dengan lahan yang lebih luas perawatan lada juga lebih sulit, selain itu responden takut apabila menanam lada dengan luasan yang lebih besar maka kerugiannya juga besar karena tanaman lada mudah mati.

\section{Biaya Produksi}

Biaya yang dikeluarkan oleh responden dalam pengolahan usahatani kakao maupun responden yang berusahatani lada meliputi biaya tetap seperti biaya penyusutan alat dan biaya pajak lahan. Sedangkan biaya variabel yaitu pupuk dan pestisida. Biaya yang dikeluarkan responden dipengaruhi oleh luas lahan yang dikelola, semakin luas lahan yang dimiliki oleh petani responden maka biaya yang dikeluarkan akan semakin besar. Besarnya rata-rata biaya produksi total yang dikeluarkan responden yang mengusahakan kakao dan yang mengusahakan lada disajikan pada Tabel 6. 
Tabel 6. Biaya Total Rata-Rata Responden, Tahun 2015

\begin{tabular}{|c|c|c|c|c|c|}
\hline No. & Jenis Usahatani & $\begin{array}{l}\text { Biaya } \\
\text { Rata-Rata } \\
\text { Responden } \\
\text { (Rp/Tahun) }\end{array}$ & Tetap & $\begin{array}{l}\text { Biaya Variabel } \\
\text { Rata-Rata } \\
\text { Responden } \\
\text { (Rp/Tahun) }\end{array}$ & $\begin{array}{l}\text { Biaya Total } \\
\text { Rata-Rata } \\
\text { Responden } \\
\text { (Rp/Tahun) }\end{array}$ \\
\hline 1. & Kakao & 61.213 & & 414.286 & 475.499 \\
\hline 2. & Lada & 34.070 & & 67.155 & 101.225 \\
\hline
\end{tabular}

Besarnya biaya total rata-rata per hektar dari usahatani kakao dan usahatani lada dapat dilihat pada Tabel 7.

Tabel 7. Biaya Total Rata-Rata per Hektar, Tahun 2015

\begin{tabular}{|c|c|c|c|c|}
\hline \multirow[b]{2}{*}{ No. } & \multirow[b]{2}{*}{ Jenis Usahatani } & Biaya Tetap Rata- & Biaya Variabel & Biaya Total Rata- \\
\hline & & $\begin{array}{l}\text { Rata per Ha } \\
(\text { Rp/Tahun) }\end{array}$ & $\begin{array}{l}\text { Rata-Rata per } \\
\text { Ha (Rp/Tahun) }\end{array}$ & $\begin{array}{l}\text { Rata per Ha } \\
\text { (Rp/Tahun) }\end{array}$ \\
\hline 1. & & 82.960 & 533.333 & 616.294 \\
\hline 2. & Lada & 101.565 & 190.000 & 291.565 \\
\hline
\end{tabular}

\section{Produksi}

Menurut Mubyarto (2000) produksi merupakan hasil fisik yang dapat diperoleh dari penggunaan faktor produksi (input). Oleh karena itu setiap petani berusaha agar usahatani yang dikelolanya dapat memberikan hasil produksi yang tinggi, sehingga diperoleh pendapatan yang lebih besar dan mampu memenuhi kebutuhan keluarganya.Besarnya produksi rata-rata yang diperoleh responden dapat dilihat pada Tabel 8 .

Tabel 8. Produksi Rata-Rata Responden, Tahun 2015

\begin{tabular}{llll}
\hline No. & Jenis Usahatani & $\begin{array}{l}\text { Produksi } \\
\text { Responden }(\mathrm{Kg} / \text { Tahun })\end{array}$ & $\begin{array}{c}\text { Rata-Rata } \\
\text { Jumlah Responden }\end{array}$ \\
\hline 1. & Kakao & 360,5 & 35 \\
2. & Lada & 85 & 29 \\
\hline
\end{tabular}

Produksi rata-rata per hektar dari masing-masing usahatani dapat dilihat pada Tabel 9.

Tabel 9. Produksi Rata-Rata per Hektar, Tahun 2015

\begin{tabular}{lllll}
\hline No. & $\begin{array}{l}\text { Jenis } \\
\text { Usahatani }\end{array}$ & $\begin{array}{l}\text { Jumlah Produksi Rata- } \\
\text { Rata } \\
\text { (Kg/Tahun) }\end{array}$ & $\begin{array}{l}\text { Luas Lahan } \\
\text { Petani } \\
\text { Rata-Rata } \\
(\mathrm{Ha})\end{array}$ & $\begin{array}{l}\text { Produksi Rata-Rata } \\
\text { per Ha (Kg/Tahun) }\end{array}$ \\
\hline 1. & Kakao & 360,5 & 0,79 & 456,33
\end{tabular}

QE Journal | Vol.04 - No.04 December 2015 - 259 

2. Lada
85
0,35
243,86

\section{Harga}

Rata-rata harga yang diterima responden disajikan pada Tabel 10.

Tabel 10. Harga Rata-Rata yang Diterima Responden, Tahun 2015

\begin{tabular}{lllll}
\hline No. & Jenis Usahatani & $\begin{array}{l}\text { Harga } \\
(\mathrm{Rp} / \mathrm{Kg})\end{array}$ & Rata-Rata & Jumlah Responden \\
\hline 1. & Kakao & 22.500 & 35 \\
2. & Lada & 72.500 & 29 \\
\hline
\end{tabular}

\section{Penerimaan}

Penerimaan rata-rata yang diperoleh responden yang berusahatani kakao dan responden yang berusahatani lada dapat dilihat pada Tabel 11.

Tabel 11. Penerimaan Rata-Rata Responden, Tahun 2015

\begin{tabular}{llll} 
No. & Jenis Usahatani & $\begin{array}{l}\text { Penerimaan } \\
\text { Responden (Rp/Tahun) }\end{array}$ & Jumlah Responden \\
\hline 1. & Kakao & 8.112 .857 & 35 \\
2. & Lada & 6.150 .000 & 29 \\
\hline
\end{tabular}

Penerimaan rata-rata per hektar dari usahatani kakao dan usahatani lada dapat dilihat pada Tabel 12.

Tabel 12. Penerimaan Rata-Rata per Hektar, Tahun 2015

\begin{tabular}{llll} 
No. & Jenis Usahatani & $\begin{array}{l}\text { Penerimaan Rata-Rata per } \\
\text { Ha (Rp/Tahun) }\end{array}$ & Jumlah Responden \\
\hline 1. & Kakao & 10.330 .714 & 35 \\
2. & Lada & 17.400 .000 & 29 \\
\hline
\end{tabular}

\section{Pendapatan Usahatani kakao dan Usahatani Lada}

Pendapatan responden yang berusahatani kakao dan pendapatan responden yang berusahatani lada dapat dilihat pada Tabel 13 . 
Tabel 13. Pendapatan Rata-Rata Responden, Tahun 2015

\begin{tabular}{lllll}
\hline No. Jenis Usahatani & $\begin{array}{l}\text { Penerimaan Rata- } \\
\text { Rata Responden } \\
\text { (Rp/Tahun) }\end{array}$ & $\begin{array}{l}\text { Biaya Total } \\
\text { Rata-Rata } \\
\text { Responden } \\
\text { (Rp/Tahun) }\end{array}$ & $\begin{array}{l}\text { Pendapatan } \\
\text { Rata-Rata } \\
\text { Responden } \\
\text { (Rp/Tahun) }\end{array}$ \\
\hline 1. $\quad$ Kakao & 8.112 .857 & 475.499 & 7.637 .358 \\
2. $\quad$ Lada & 6.150 .000 & 101.225 & 6.048 .775 \\
\hline
\end{tabular}

Pendapatan rata-rata per hektar dari masing-masing usahatani disajikan pada Tabel 14.

Tabel 14. Pendapatan Rata-Rata per Hektar, Tahun 2015

\begin{tabular}{llllrlr}
\hline & & Penerimaan & Biaya & Total & Pendapatan \\
No. Jenis Usahatani & $\begin{array}{l}\text { Rata-Rata per } \\
\text { Ha (Rp/Tahun) }\end{array}$ & $\begin{array}{l}\text { Rata-Rata per } \\
\text { Ha (Rp/Tahun) }\end{array}$ & $\begin{array}{l}\text { Rata per } \\
(\text { Rp/Tahun) }\end{array}$ & Ha \\
\hline 1. & Kakao & 10.330 .714 & 616.294 & 9.714 .420 & \\
2. & Lada & 17.400 .000 & 291.565 & 17.108 .435 & \\
\hline
\end{tabular}

Perbedaan Pendapatan Usahatani Kakao dan Usahatani Lada

Hasil dari analisis uji beda t-test untuk rata-rata responden dapat dilihat pada Tabel 15.

Tabel 15. Perbedaan Pendapatan Responden, Tahun 2015

\begin{tabular}{llllll}
\hline No. Usahatanitanai & $\begin{array}{l}\text { Jumlah } \\
\text { Sampel }\end{array}$ & $\begin{array}{l}\text { Pendapatan } \\
\text { Rata-Rata } \\
\text { Responden } \\
\text { (Rp/Tahun) }\end{array}$ & Sig.(2-tailed) & t-hitung \\
\hline $1 . \quad$ Kakao & 35 & 7.637 .358 & 0,024 & 2,313 \\
\hline
\end{tabular}

Perbedaan pendapatan per hektar dari usahatani kakao dan usahatani lada dapat dilihat pada Tabel 16.

Tabel 16. Perbedaan Pendapatan per Hektar, Tahun 2015

\begin{tabular}{llllll}
\hline No. Usahatanitanai & $\begin{array}{l}\text { Jumlah } \\
\text { Sampel }\end{array}$ & $\begin{array}{l}\text { Pendapatan } \\
\text { Rata-Rata per Ha } \\
\text { (Rp/Tahun) }\end{array}$ & Sig.(2-tailed) & t-hitung \\
\hline 1. & Kakao & 35 & 9.714 .420 & 0,000 & 12,468 \\
\hline
\end{tabular}


Hasil uji t-test memperlihatkan bahwa dari usahatani kakao dan usahatani lada terdapat perbedaan pendapatan yang nyata baik pendapatan rata-rata per responden maupun pendapatan per hektar, dimana perbedaan pendapatan tersebut dipengaruhi oleh faktor produksi seperti penggunaaan pupuk dan pestisida untuk usahatani kakao lebih banyak daripada penggunaaan pupuk dan pestisida untuk usahatani lada sehingga produktivitas kakao lebih banyak dan pendapatan yang diperoleh per responden akan lebih besar. Namun harga lada yang lebih tinggi daripada kakao memberikan kontribusi pendapatan untuk usahatani lada per hektarnya. Sehingga dilihat dari pendapatan per hektarnya maka usahatani lada akan memberikan pendapatan yang lebih besar. Selain dari harga lada yang lebih mahal, luas lahan juga mempengaruhi pendapatan per hektar karena dari penerimaan usahatani kakao dikurangi dengan biaya total usahatani kakao yang besar maka pendapatannya juga kecil. Sedangkan penerimaan rata-rata per hektar usahatani lada dikurangi dengan biaya total per hektarnya yang masih sedikit penggunaan pupuk dan pestisida maka pendapatannya lebih besar dari usahatani kakao. Pendapatan per responden dihitung untuk mengetahui berapa besarnya pendapatan dari masing-masing responden. Dan pendapatan per hektar dihitung untuk melilihat pendapatan responden jika luas lahan yang dimiliki seluas satu hektar.

Berdasarkan paparan di atas bahwa lokasi penelitian memiliki komoditas unggulan perkebunan yaitu kakao dan lada dimana kedua usahatani tersebut memiliki pendapatan yang berbeda. Masing-masing responden tetap mempertahankan usahataninya tersebut, dimana kedua usahatani memiliki kelebihan dan kekurangan yaitu kakao lebih unggul pada jumlah produktivitasnya karena selain memiliki lahan yang lebih luas dari lada, kakao pemanenannya bisa setiap minggu. Sedangkan kekurangannya yaitu harga lada masih rendah karena kualitas kakao masih rendah belum dilakukan proses fermentasi. Kelebihan lada yaitu harga jualnya tinggi daripada kakao dan kekurangannya tanaman lada produktivitasnya masih sedikit dan tanaman lada cepat mati karena serangan penyakit busuk batang. Dari kelebihan dan kekurangan tersebut sebenarnya responden belum maksimal dalam melakukan proses budidaya yang baik, dimana perawatan tanaman tidak terlalu diperhatikan dan pemupukan tanaman belum dilakukan sesuai anjuran. Jika proses budidaya diperbaiki dengan baik maka dengan luas lahan komoditas lada yang sempit bisa 
menghasilkan pendapatan yang maksimal dan jika proses pasca panen diperhatikan seperti melakukan fermentasi pada biji kakao maka harga kakao bisa lebih mahal dan pendapatannya juga bisa lebih maksimal.

\section{KESIMPULAN DAN SARAN}

\section{Kesimpulan}

Berdasarkan dari hasil penelitian dan pembahasan, maka diperoleh kesimpulan bahwa:

1. Pendapatan rata-rata responden yang berusahatani kakao Rp 7.637.358/Tahun dan pendapatan rata-rata per hektar yaitu Rp 9.714.420/Tahun. Pendapatan rata-rata responden yang berusahatani lada yaitu Rp 6.048.775/Tahun dan pendapatan rata-rata per hektar sebesar Rp 17.108.435/Tahun.

2. Pendapatan rata-rata responden yang berusahatani kakao secara signifikansi berbeda nyata dengan pendapatan rata-rata responden yang berusahatani lada. Pendapatan usahatani lada rata-rata per hektar secara signifikansi berbeda nyata dengan pendapatan rata-rata usahatani kakao.

\section{Saran}

Saran yang dapat disampaikan penulis berdasarkan hasil penelitian yang dilakukan yaitu:

1. Kepada responden baik yang berusahatani kakao maupun yang berusahatani lada diharapkan dapat memperbaiki cara budidaya agar dapat meningkatkan produktivitasnya, dan memperbaiki cara pengolahan sebelum menjual biji kakao dan biji lada agar kualitas produksi tinggi sehingga harga yang diterima responden juga lebih tinggi dari harga yang diterima sebelumnya.

2. Pendapatan usahatani kakao secara per responden lebih tinggi daripada pendapatan usahatani lada, namun pada kondisi per hektarnya pendapatan usahatani lada lebih tinggi daipada pendapatan usahatani kakao, oleh karena itu disarankan kepada penelitian selanjutnya untuk melakukan penelitian atau studi lanjut terkait pada QE Journal | Vol.04 - No.04 December 2015 - 263 
kondisi seperti apa kakao maupun lada dapat menghasilkan produktivitas yang maksimal.

\section{DAFTAR PUSTAKA}

Badan Pusat Statistik. 2014a. Sulawesi Tenggara dalam Angka 2014. Badan Pusat Statistik Sulawesi Tenggara. Kendari.

Badan Pusat Statistik. 2014b. Laeya dalam Angka 2014. Badan Pusat Statistik Sulawesi Tenggara. Kendari.

BAPPEBTI. 2015. Harga Komoditi. Kementrian Perdagangan. Jakarta.

Dinas Perkebunan. 2014. Perkembangan Harga Rata-Rata Bulanan Komoditi Perkebunan di Tingkat Petani/Produsen. Dinas Perkebuan Sulawesi Tenggara. Kendari.

Gusti, A.I.J., D. Haryono, dan F.E. Prasmatiwi. 2013. Pendapatan Rumah Tangga Petani Kakao di Desa Pesawaran Indah Kecamatan Padang Cermin Kabupaten Pesawaran. Universitas Lampung. Jurnal IlmuIlmu Agribisnis 1(4):278-283.

Hermanto, F. 1989. Ilmu Usaha Tani. Penebar Swadaya. Jakarta.

Kecamatan Laeya. 2013. Profil Kecamatan Laeya. Kantor Camat Laeya. Konawe Selatan.

Mubyarto. 2000. Pengantar Ekonomi Pertanian. LP3ES. Jakarta.

Nirmalasari, F.O., M. Marhawati, dan M.N. Alam. 2013. Analisis Perbandingan Pendapatan Usaha Gula Merah dengan Usaha Gula Tapo (Studi Kasus di Desa Ambesia Kacamatan Tomini Kabupaten Parigi Moutong). Jurnal Agrotekbis 1 (1) : 60-66.

Sugiyono. 2011. Metode Penelitian Kuantitatif, Kualitatif, Dan R\&D. Alfabeta, Cv. Bandung.

Suratiyah, K. 2006. Ilmu Usahatani. Penebar Swadaya. Jakarta. 